Original Contribution

\title{
CONTRIBUTION TO THE KNOWLEDGE OF NYMPHALIDAE FAUNA (LEPIDOPTERA: RHOPALOCERA) IN KOSOVO
}

\author{
F. N. Zhushi ${ }^{1 *}$, P. S. Bytyci ${ }^{2}$, M. A. Ismail ${ }^{2}$, M. Q. Musliu ${ }^{2}$ \\ ${ }^{1}$ Department of Biology, Faculty of Mathematics and Natural Sciences, University "Hasan Prishtina", \\ Prishtina, Kosovo \\ ${ }^{2}$ Southeast European University (SEEU), Tetovo, FYR Macedonia
}

\begin{abstract}
Insects of the order Lepidoptera are among the most explored in Europe. This order is presented with a rich variety, especially in the Balkan Peninsula, which includes also the state of Kosovo. In this paper the results of the research of Nymphalidae family in the region of Llapusha in Kosovo, specifically in the southern part of the mountain ranges of Shkoza, for the period April to July 2016 are presented. As a result of this research 35 species of Nymphalidae butterflies have been recorded, among them Melanargia russiae (Esper 1783) as a new species for Kosovo. This research is conducted five years after a first study of butterflies in this region took place and four years after the wildfire occurred in the area, which destroyed a large part of the vegetation. After this period, as a result of secondary succession, there is a renewal of vegetation, and a significant number of Nymphalidae butterflies.
\end{abstract}

Key words: Butterflies, mountain range Shkoza, biodiversity, fire

\section{INTRODUCTION}

The existing data on the Lepidoptera fauna in Kosovo include mainly those from Rebel and Zerny $(1,2)$ and Jakšić (3-5) that were conducted in national parks Sharri and Bjeshkët e Nemuna (Accursed Mountain) and the mountain of Pashtriku. The mountain range of Shkoza is located in the central part of Kosovo and they divide the region of Llapusha from the Anadrini region. Its terrain configuration is hilly mountainous with an altitude of $640 \mathrm{~m}$ up to $893 \mathrm{~m}$. The initial part of the mountain range is characterized by low mountains in the North and North West, while in the Northeastern part begins a narrow valley. The climate of this region is continental, with some different elements of Mediterranean climate, which is characterized by cold winters and long, hot and dry summers. Because of the limestone composition of rocks, the soil composition is "terra rossa" (red soil). The geologic structure, altitude and weather conditions have contributed that this area has a pretty rich diversity of flora and fauna.

\footnotetext{
*Correspondence to: Ferdije Zhushi Etemi, Department of Biology, Faculty of Mathematics and Natural Sciences, University "Hasan Prishtina"- Pristina "Mother Theresa" street nr.5 10000 Prishtina, Kosovo; Fax: +38138244187 ferdijezhushi2010@gmail.com; tel:+37744249636
}

The massif area of Shkoza is very rich in plant species starting from those low up to vascular one. In this region appears the plant association Quercetum pubescentis-cerris (6). Due to the large presence of wood hornbeam - Carpinus betullus (White hornbeam) and Carpinus orinetalis (black hornbeam), these ridges were named Shkoza - Hornbeam. Characteristic of this region is the drought during the summer due to the insufficiency of water resources.

\section{MATERIAL AND METHOD}

The research was conducted during the months April to July 2016 in 11 localities in the massif of Shkoza (Figure 1). The butterflies were collected by entomological net; they were observed, photographed and identified in the field, only a number of samples were preserved for further studies. The determination is performed in Zoology lab at the Department of Biology of the University of Prishtina "Hasan Prishtina". Identification is based according to Tolman and Lewington (7) and Misja (8). In addition to these sources, the website www.lepiforum.de (11) was consulted.

\section{Data calculation}

Species richness, number of specimensabundance, Shannon-Wiener diversity index $\mathrm{H}^{\prime}$ (diversity of species in a sample), Evenness index $\mathrm{E}$ (quantitative representation of specimens among species in a sample) and 
Sörensen'ssimilarity index-So, were calculated

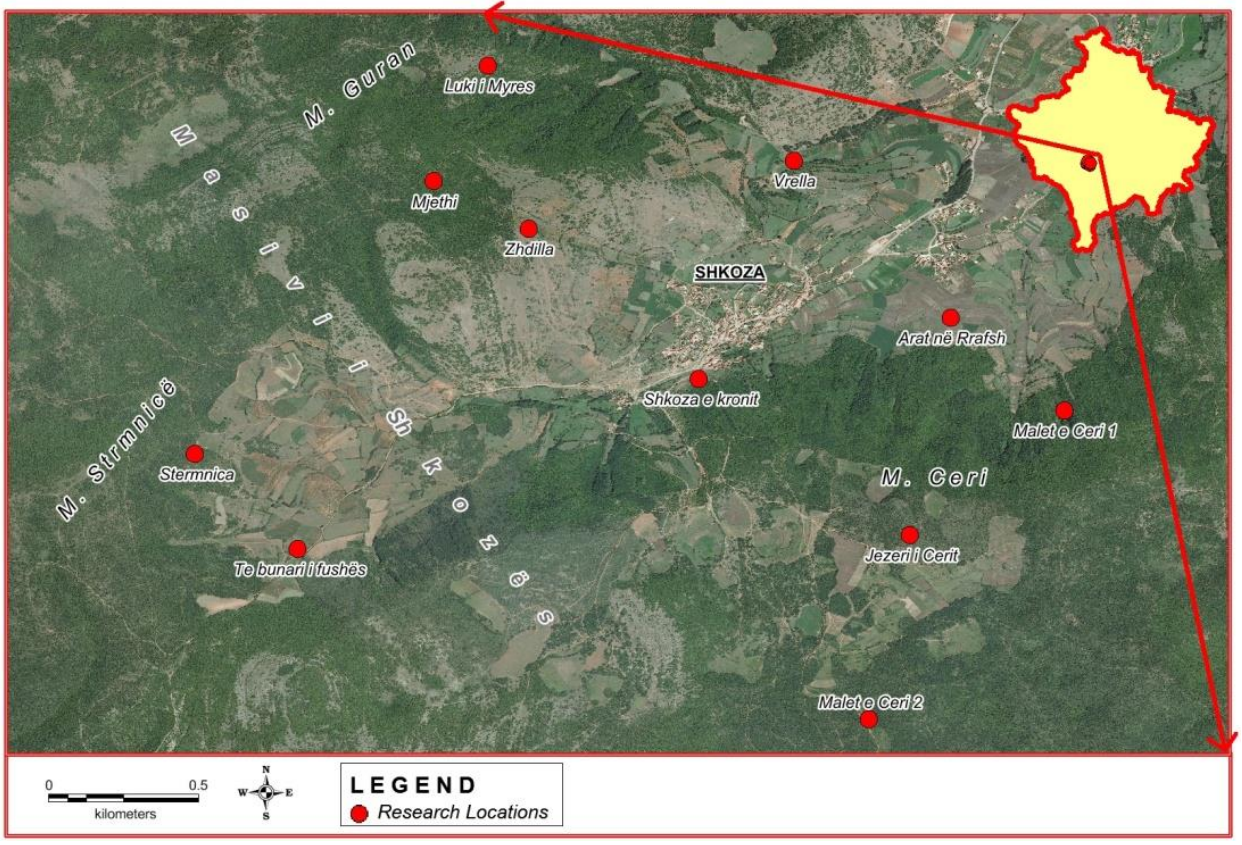

Figure 1. Map with surveyed localities

Table 1. Surveyed localities with habitat types, coordinates and altitude

\begin{tabular}{|l|l|l|l|c|}
\hline & Localities & \multicolumn{1}{|c|}{ N } & E & Altitude \\
\hline $\mathbf{1 .}$ & $\begin{array}{l}\text { Mjethi (Dry meadows with } \\
\text { pastures ) }\end{array}$ & $42^{\circ} 25^{\prime} 00.40^{\prime \prime}$ & $20^{\circ} 42^{\prime} 06.19^{\prime \prime}$ & $712 \mathrm{~m}$ \\
\hline $\mathbf{2 .}$ & $\begin{array}{l}\text { Te bunari i fushes (Agro } \\
\text { ecosystems with water springs } \\
\text { in the vicinity and animal } \\
\text { stables) }\end{array}$ & $42^{\circ} 24^{\prime} 45.57^{\prime \prime}$ & $20^{\circ} 41^{\prime} 46.10^{\prime \prime}$ & $706 \mathrm{~m}$ \\
\hline $\mathbf{3 .}$ & $\begin{array}{l}\text { Stermnica (Woodland } \\
\text { combined with grasslands } \\
\text { with many pioneer species } \\
\text { occurred after the fire in } \\
\text { 2012) }\end{array}$ & $42^{\circ} 25^{\prime} 00.2^{\prime \prime}$ & $20^{\circ} 41^{\prime} 30.95^{\prime \prime}$ & $765 \mathrm{~m}$ \\
\hline $\mathbf{4 .}$ & $\begin{array}{l}\text { Zhdilla( Dry meadows with } \\
\text { mixed woodland) }\end{array}$ & $42^{\circ} 25^{\prime} 32.44^{\prime \prime}$ & $20^{\circ} 42^{\prime} 19.54^{\prime \prime}$ & $753 \mathrm{~m}$ \\
\hline $\mathbf{5 .}$ & $\begin{array}{l}\text { Arat në Rrafsh } \\
\text { (Agroecosystems) }\end{array}$ & $42^{\circ} 25^{\prime} 19.72^{\prime \prime}$ & $20^{\circ} 43^{\prime} 21.71^{\prime \prime}$ & $576 \mathrm{~m}$ \\
\hline $\mathbf{6 .}$ & $\begin{array}{l}\text { Vrella (Agroecosystems with } \\
\text { water springs in the vicinity) }\end{array}$ & $42^{\circ} 25^{\prime} 42.87^{\prime \prime}$ & $20^{\circ} 42^{\prime} 58.49^{\prime \prime}$ & $574 \mathrm{~m}$ \\
\hline $\mathbf{7 .}$ & $\begin{array}{l}\text { Malet e Cerit } 1 \text { (Woodland } \\
\text { and woodland margins) }\end{array}$ & $42^{\circ} 43^{\prime} 39.56^{\prime \prime}$ & $20^{\circ} 43^{\prime} 39.56^{\prime \prime}$ & $683 \mathrm{~m}$ \\
\hline $\mathbf{8 .}$ & $\begin{array}{l}\text { Malet e Cerit 2 (Woodland } \\
\text { with alpine meadows ) }\end{array}$ & $42^{\circ} 24^{\prime} 20.96^{\prime \prime}$ & $20^{\circ} 43^{\prime} 10.22^{\prime \prime}$ & $756 \mathrm{~m}$ \\
\hline $\mathbf{9 .}$ & $\begin{array}{l}\text { Shkoza e kronit (Inside the } \\
\text { settlements, near the area with } \\
\text { wastes ) }\end{array}$ & $42^{\circ} 25^{\prime} 10.51^{\prime \prime}$ & $20^{\circ} 42^{\prime} 45.32^{\prime \prime}$ & $623 \mathrm{~m}$ \\
\hline $\mathbf{1 0 .}$ & $\begin{array}{l}\text { Jezeri i Cerit( Woodland with } \\
\text { dry rocky meadows) }\end{array}$ & $42^{\circ} 24^{\prime} 48.37^{\prime \prime}$ & $20^{\circ} 43^{\prime} 15.72^{\prime \prime}$ & $751 \mathrm{~m}$ \\
\hline $\mathbf{1 1 .}$ & $\begin{array}{l}\text { Luki i Myres (Woodland } \\
\text { combined with mixed rocky } \\
\text { meadows }\end{array}$ & $42^{\circ} 25^{\prime} 56.79^{\prime \prime}$ & $20^{\circ} 42^{\prime} 13.56^{\prime \prime}$ & $745 \mathrm{~m}$ \\
\hline
\end{tabular}


Table 2. List of the butterfly species of the family Nymphalidae recorded in the studied area, the localities of the record (according to the numbers in the Map of localities) and their IUCN status

\begin{tabular}{|c|c|c|}
\hline $\begin{array}{l}\text { Class: Insecta } \\
\text { Order: Lepidoptera } \\
\text { Family: Nymphalidae }\end{array}$ & $\begin{array}{l}\text { Locality where the species } \\
\text { is recorded }\end{array}$ & $\begin{array}{l}\text { Threatened status } \\
\text { according to IUCN }\end{array}$ \\
\hline $\begin{array}{l}\text { Arethusana arethusa (Denis\& } \underline{\text { Schiffermüller, }} \\
\text { 1775) }\end{array}$ & 3,10 & $L C$ \\
\hline Issoria lathonia (Linnaeus,1758) & $1,2,3,4,5,6,7,8,9,10,11$ & $L C$ \\
\hline Boloria dia (Linnaeus,1767) & $1,2,3,4,5,6,7,8,9,10,11$ & $L C$ \\
\hline Brenthis hecate (Denis \& Schiffermüller,1775) & $1,2,4,5,6,9,10$ & $L C$ \\
\hline Brenthis daphne (Denis \& Schiffermüller,1775) & $1,2,3,10$ & $L C$ \\
\hline Agalis urticae (Linnaeus, 1758) & 1,6 & $L C$ \\
\hline Argynis niobe (Linnaeus, 1758) & $1,2,3,4,5,6,7,8,9,10,11$ & $L C$ \\
\hline Aglais io (Linnaeus,1758) & $1,2,4$ & $L C$ \\
\hline Argynnis pahia (Linnaeus,1758) & $1,2,3,4,5,6,7,8,9,10,11$ & $L C$ \\
\hline Argynnis aglaja (Linnaeus,1758) & $1,2,3,4,5,6,7,8,9,10,11$ & $L C$ \\
\hline Coenonympha pamphilus (Linnaeus,1758) & $1,2,3,4,5,6,7,8,9,10,11$ & $L C$ \\
\hline Vanessa atalanta (Linnaeus,1758) & $1,2,3,4,5,6,7,8,9,10,11$ & $L C$ \\
\hline Vanessa cardui (Linnaeus,1758) & $1,2,3,4,5,6,7,8,9,10,11$ & $L C$ \\
\hline Polygonia c- album (Linnaeus,1758) & 1,2 & $L C$ \\
\hline Chazara briseis (Linnaeus, 1764) & 4 & $N T$ \\
\hline Melitaea triva (Denis \& Schiffermüller,1775) & $1,2,3,4,5,6,7,8,9,10,11$ & $L C$ \\
\hline Melitaea cinixia (Linnaeus,1758) & $1,2,3,4,5,6,7,8,9,10,11$ & $L C$ \\
\hline Melitaea didyma (Esper, 1778) & $1,2,3,4,5,6,7,8,9,10,11$ & $L C$ \\
\hline Melitaea athalia (Rottemburg, 1775) & $3,7,8,10$ & $L C$ \\
\hline Melitaea phoebe (Denis \& Schiffermüller,1775) & $1,2,3,4,5,6,7,8,9,10,11$ & $L C$ \\
\hline Melanargia galathea (Linnaeus,1758) & $1,2,3,4,5,6,7,8,9,10,11$ & $L C$ \\
\hline Melanargia larissa (Geyer,1828) & $1,2,4,5$ & $L C$ \\
\hline Melanargia russiae (Esper,1783) & 2,4 & $L C$ \\
\hline Ceononympha arcania $($ Linnaeus, 1761$)$ & 3 & $L C$ \\
\hline Boloria euphrosyne (Linnaeus,1758) & $1,2,3,4,5,6,7,8,9,10,11$ & $L C$ \\
\hline Maniola jurtina (Linnaeus,1758) & $1,2,3,4,5,6,7,8,9,10,11$ & $L C$ \\
\hline Hipparchia fagi (Scopoli,1763) & $7,8,10,11$ & $N T$ \\
\hline $\begin{array}{l}\text { Hipparchia volgensis (Mazochin - Porshnjakov, } \\
\text { 1952) }\end{array}$ & $1,2,7,10,11$ & $L C$ \\
\hline Hipparchia fatua (Freyer, 1844) & 8,10 & $L C$ \\
\hline Hipparchia syriaca (Staudinger, 1871) & $2,3,4,7,8,9,10,11$ & $L C$ \\
\hline Hipparchia statilinus ( Hufnagel, 1766) & 8,10 & $N T$ \\
\hline Hyponephele lupines (Costa,1776) & $1,2,3,4,6,7,8,9,10,11$ & $L C$ \\
\hline Kirinia roxelana (Cramer, 1777$)$ & $1,2,3,4,5,6,7,8,9,10,11$ & $L C$ \\
\hline Limenitis reducta (Staudinger, 1901) & $1,2,3,4,5,6,7,8,9,10,11$ & $L C$ \\
\hline Lasiommata megera (Linnaeus,1767) & $1,2,3,4,5,6,7,8,9,10,11$ & $L C$ \\
\hline
\end{tabular}

Table 3. Species richness (S), number of specimens-abundance (N),Shannon-Wiener diversity index $\left(H^{\prime}\right)$ and Evenness $-E$, for each sampling locality

\begin{tabular}{|c|c|c|c|c|c|c|c|c|c|c|c|}
\hline Indices & \multicolumn{11}{|c|}{ Surveyed localities } \\
\hline & 1 & 2 & 3 & 4 & 5 & 6 & 7 & 8 & 9 & 10 & 11 \\
\hline Species richness-S & 26 & 27 & 24 & 25 & 20 & 19 & 23 & 24 & 22 & 27 & 22 \\
\hline Abundance $-\mathrm{N}$ & 160 & 125 & 124 & 110 & 107 & 94 & 98 & 141 & 126 & 137 & 113 \\
\hline $\begin{array}{l}\text { Shannon Wiener } \\
\text { diversity index- H' }\end{array}$ & 4.46 & $\begin{array}{l}4.5 \\
6\end{array}$ & $\begin{array}{l}4.4 \\
2\end{array}$ & $\begin{array}{l}4.4 \\
1\end{array}$ & $\begin{array}{l}4.0 \\
6\end{array}$ & $\begin{array}{l}4.0 \\
5\end{array}$ & $\begin{array}{l}4.2 \\
5\end{array}$ & $\begin{array}{l}4.3 \\
9\end{array}$ & $\begin{array}{l}4.3 \\
4\end{array}$ & 4.58 & 4.30 \\
\hline Evenness - E & $\begin{array}{l}0.95 \\
0\end{array}$ & $\begin{array}{l}0.9 \\
6\end{array}$ & $\begin{array}{l}0.9 \\
6\end{array}$ & $\begin{array}{l}0.9 \\
5\end{array}$ & $\begin{array}{l}0.9 \\
7\end{array}$ & $\begin{array}{l}0.9 \\
6\end{array}$ & $\begin{array}{l}0.9 \\
3\end{array}$ & $\begin{array}{l}0.9 \\
4\end{array}$ & $\begin{array}{l}0.9 \\
4\end{array}$ & 0.96 & 0.96 \\
\hline
\end{tabular}


Table 4. Sörensen's similarity index-So

\begin{tabular}{|l|l|l|l|l|l|l|l|l|l|l|}
\hline So & Sam.2 & Sam.3 & Sam.4 & Sam.5 & Sam.6 & Sam.7 & Sam.8 & Sam.9 & Sam.10 & Sam.11 \\
\hline Sam.1 & $94 \%$ & $80 \%$ & $86 \%$ & $87 \%$ & $84 \%$ & $82 \%$ & $76 \%$ & $83 \%$ & $83 \%$ & $83 \%$ \\
\hline Sam.2 & & $82 \%$ & $92 \%$ & $85 \%$ & $78 \%$ & $84 \%$ & $78 \%$ & $86 \%$ & $85 \%$ & $86 \%$ \\
\hline Sam.3 & & & $82 \%$ & $82 \%$ & $84 \%$ & $89 \%$ & $88 \%$ & $91 \%$ & $86 \%$ & $87 \%$ \\
\hline Sam.4 & & & & $89 \%$ & $82 \%$ & $83 \%$ & $82 \%$ & $89 \%$ & $81 \%$ & $85 \%$ \\
\hline Sam.5 & & & & & $87 \%$ & $84 \%$ & $82 \%$ & $90 \%$ & $81 \%$ & $86 \%$ \\
\hline Sam.6 & & & & & & $86 \%$ & $84 \%$ & $88 \%$ & $78 \%$ & $88 \%$ \\
\hline Sam.7 & & & & & & $94 \%$ & $93 \%$ & $88 \%$ & $98 \%$ \\
\hline Sam.8 & & & & & & & & $91 \%$ & $90 \%$ & $91 \%$ \\
\hline Sam.9 & & & & & & & & & $86 \%$ & $91 \%$ \\
\hline Sam.10 & & & & & & & & & & $90 \%$ \\
\hline
\end{tabular}

Table 5. Number of Nymphalidae species recorded in some of the mountain areas in Republic of Kosovo

\begin{tabular}{|l|l|l|l|l|}
\hline $\begin{array}{l}\text { Family } \\
\text { Nymphalidae }\end{array}$ & $\begin{array}{l}\text { Massif of } \\
\text { Shkoza }\end{array}$ & $\begin{array}{l}\text { National Park } \\
\text { Sharri }\end{array}$ & $\begin{array}{l}\text { National Park } \\
\text { Bjeshket e } \\
\text { Nemuna }\end{array}$ & $\begin{array}{l}\text { Pashtrik } \\
\text { Mountain }\end{array}$ \\
\hline $\begin{array}{l}\text { Number of } \\
\text { recorded species }\end{array}$ & 35 & 65 & 68 & 38 \\
\hline
\end{tabular}

\section{DISCUSSION}

As shown in Table 2 in the researched area 35 species of the Nymphalidae butterflies have been recorded, which represents a fairly prosperous diversity for this region. 19 species were present in all localities of the research,whereas 2 species were recorded only in one of the localities. In this research the species Melanargia russiae (ESPER, 1783) was recorded for the first time in Kosovo. Melanargia russiae is recorded in June and July in several habitats throughout the village where its caterpillar live on various gramineae plants of the family Poaceae. This species is also reported in the neighboring countries of Kosovo. According to the earlier records (8), in Albania Melanargia russiae was found only in the Tomorri Mountain, but the most recent data on the butterflies of Albania (9) have shown that Melanargia russiae is fairly widespread and recorded in eight (8) observation locations on the territory of Albania.

It is worth noting the large presence of Hipparchia volgensis (Mazochin Porshnjakov, 1952), an European endemic species, during the month of June in the territory of Shkoza in dry and hot areas, habitats of deciduous forests, in arid hills areas and different rock slopes and in the compound silicate soils in some of the surveyed localities. (Table 2) This species is presented with a large number of specimens, thus in a numerically large population. According the data from the IUCN Red List of Threatened Species (2016) this species is native in Bulgaria, Greece, FYR
Macedonia, Romania, Serbia, the Russian Federation and Turkey. Its appearance varies at different altitudes from 600 to $1.500 \mathrm{~m}$, sometimes $2.500 \mathrm{~m}$. According to the literature (7) this species has spread in Albania too. In Kosovo this species was earlier reported in the Pashtrik Mountain (5) as Hipparchia delattini (Kudrna, 1975).

Regarding the species richness, all the surveyed localities hosted more than $50 \%$ of species. However the richest were localities 2 and 10 with 27 species out of recorded 35.These two localities have also the highest value of Shannon -Wiener diversity index, $\mathrm{H}^{\prime}=4.56$, respectively 4.58 ,indicating the high species diversity in a sample. The quantitative (numerically) distribution of individuals among species, evenness $\mathrm{E}$ index has a high value ranging from 0.93 to 0.97 in all surveyed localities, indicating that relatively equal numbers of individuals belong to each species. In respect to abundance $\mathrm{N}$, the highest number of specimens, total 160 , is recorded in the locality 1 , whereas the poorest was in locality 6 with only 94 . (Table 3)

Based on the values of Sörensen's similarity index-So (Table 4) it can be seen that all the localities in our survey share almost $80 \%$ of species. The highest similarity in species composition was registered between the localities 1 and 2, So=94\%, with 25 shared species. The lowest similarity, $76 \%$ was between localities 1 and 8 wich 17 shared species. The difference in species composition between these two localities can be justified 
as the result of different habitat types in these two localities. (Table 1)

Based on the European Red List of Butterflies (10) from 35 species recorded in our research, 29 species belong to the category LC (Least Concern), three other species: Hipparchia fagi, Hipparchia statilinus and Chazara briseis belonging to the category NT (Near threatened). In a research conducted in 2011 in the same area total of 44 butterflies species were recorded, 22 of them from the family Nymphalidae. It is worth mentioning that during that time the field visits have not been on regular basis, which can justify the small number of species encountered in comparison with this research. A year later a big part of this massif was burned, and then, four years later, the secondary succession took place, where a number of pioneer species appeared. It remains to be discussed the question of whether the largest number of butterflies species in this research is the result of more frequent field visits or is it because of the change of the vegetation as a result of secondary succession, four years after the wildfire in this part of the mountain. However, given the fact that the family Nymphalidae is the most widespread family of butterflies in Europe, (10) it turns out that this family is also pretty widespread in our country. Comparing the number of 35 Nymphalidae species recorded in our research with the number of species from previous research in territory of the Republic of Kosovo (Table 2), it is very close with Pashtrik Mountain (5) where 38 species were found. This is expected due to very similar geologic structure and climate conditions of these two mountains. The richest butterfly fauna of Nymphalidae family, composed from 69 species was recorded from National Park "Bjeshket e Nemuna"(4) located in the western part of Kosovo. A pretty high number of Nymphalidae species-65, was also registered in both sited of National Park Sharri that lies on the border between Kosovo and Macedonia (3).

\section{CONCLUSION}

As a result of this research, we came to the conclusion that thanks to bio-geological, geographic and climatic characteristics of the researched area, Shkoza massif presents a rich diversity of the fauna of butterflies. The recorded Nymphalidae species in this area constitutes approximately $14 \%$ of the number of European Nymphalidae species and more than $50 \%$ of species recorded in our country.However, to know fully the butterfly diversity in this mountain massif, the research should be expanded throughout its length, with more attention to be given to dry, open rocky habitats where the presence of some other species may be expected.

Furthermore, research should be repeated in areas previously surveyed in order to follow the changes in the diversity of butterfly fauna, considering the long time that has elapsed and the changes that have swept the country over the past two decades.

\section{REFERENCES}

1. Rebel, $H$. Neue Lepidopterenfunde in Nordalbanien, Mazedonien und Serbien. Jahresber. Naturë. Orientverein, 21: 17-24. 1917.

2. Rebel, $\mathrm{H}$ \& Zerny, H. Die Lepidopterenfauna Albaniens. Denkschriften der Akademie der Wissenschaften in Wien, Mat.- Nat. Kl., 103 Band. Wien, 1931.

3. Jakšić, P.. Dnevni leptiri (Lepidoptera: Hesperioidea i Papilionoidea) Šar-planine. [The butterflies of Šar-planina Mt. (Lepidoptera: Hesperioidea \& Papilionoidea)]. Zaštita prirode, 50: 229252, Beograd. 1998.

4. Jakšić, P.. Dnevni leptiri Prokletija (Lepidoptera: Hesperioidea i Papilionoidea). [The butterflies of the former Yugoslavian Prokletije Mt. (Lepidoptera: Hesperioidea i Papilionoidea)]. Zbornik radova o fauni Srbije, SANU, Odeljenje hemijskih i bioloških nauka, Knjiga VII: 87-104, Beograd. 2006.

5. Jakšić, P..Contribution to knowledge of the butterflies of Mt. Paštrik, Serbia (Lepidoptera: Hesperioidea \& Papilionoidea). [Prilog poznavanju dnevnih leptira Paštrika, Srbija (Lepidoptera: Hesperioidea \& Papilionoidea)]. Acta entomologica serbica, 12(2): 55-61, Beograd, 2007.

6. RexhepiF..Vegetation of Kosova. Prishtine:University of Prishtina; 1994

7. Tolman, T. \& Lewington, R. Collins butterfly guide. HarperCollins Publishers, London, 384 pp. 2008.

8. Misja, K.Fluturat e Shqiprisë. Tiranë: Akademia e shkencave e Shqiprisë. 2005.

9. Šašić M. et al..Contribution to the knowledge of the butterfly fauna of Albania.Nota Lepidopterologica 38(1): 2945,2015

10.Van Swaay et al. European Red List of Butterfies Luxembourg: Publications Office of the European Union. 2010

11.http://www.lepiforum.de/

12.http://prf.osu.cz/kbe/dokumenty/sw/ComEc oPaC/ComEcoPaC.xls. 
